\title{
Heme oxygenase-1 improves the survival of ischemic skin flaps (Review)
}

\author{
YINHUA ZHENG ${ }^{1}$, ZHENLAN LI ${ }^{2}$, MIN YIN $^{3}$ and XU GONG ${ }^{1}$ \\ Departments of ${ }^{1}$ Hand and Foot Surgery, and ${ }^{2}$ Rehabilitation Medicine, The First Hospital of Jilin University, \\ Changchun, Jilin 130021; ${ }^{3}$ Department of Nephrology, China-Japan Union Hospital of Jilin University, \\ Changchun, Jilin 130033, P.R. China
}

Received September 22, 2020; Accepted January 12, 2021

DOI: $10.3892 / \mathrm{mmr} .2021 .11874$

\begin{abstract}
Heat shock protein 32 (Hsp32), also known as heme oxygenase-1 (HO-1), is an enzyme that exists in microsomes. HO-1 can be induced by a variety of stimuli, including heavy metals, heat shock, inflammatory stimuli, heme and its derivatives, stress, hypoxia, and biological hormones. HO-1 is the rate-limiting enzyme of heme catabolism, which splits heme into biliverdin, carbon monoxide $(\mathrm{CO})$ and iron. The metabolites of HO-1 have anti-inflammatory and anti-oxidant effects, and provide protection to the cardiovascular system and transplanted organs. This review summarizes the biological characteristics of HO-1 and the functional significance of its products, and specifically elaborates on its protective effect on skin flaps. HO-1 improves the survival rate of ischemic skin flaps through anti-inflammatory, anti-oxidant and vasodilatory effects of enzymatic reaction products. In particular, this review focuses on the role of carbon monoxide $(\mathrm{CO})$, one of the primary metabolites of $\mathrm{HO}-1$, in flap survival and discusses the feasibility and existing challenges of HO-1 in flap surgery.
\end{abstract}

Correspondence to: Dr Xu Gong, Department of Hand and Foot Surgery, The First Hospital of Jilin University, 71 Xinmin Street, Changchun, Jilin 130021, P.R. China

E-mail: gongxu@jlu.edu.cn

Abbreviations: Hsp32, heat shock protein 32; HO-1, heme oxygenase-1; CO, carbon monoxide; sGC, soluble guanylate cyclase; cGMP, cyclic guanosine monophosphate; ROS, reactive oxygen species; CORM, carbon monoxide-releasing molecules; BBB, blood-brain barrier; ICAM-1, intercellular adhesion molecule-1; $\mathrm{NF}-\kappa \mathrm{B}$, nuclear factor $\kappa \mathrm{B}$; iNOS, inducible nitric oxide synthase; PMN, polymorphonuclear; TNF- $\alpha$, tumor necrosis factor $\alpha$; IL, interleukin; MIP, macrophage inflammatory protein; hBVR, human biliverdin reductase; ERK, extracellular signal regulated kinase; RONS, reactive oxygen and nitrogen species; eNOS, endothelial nitric oxide synthase; PKC, protein kinase C; MAPK, mitogen activated protein kinase; HIF-1 $\alpha$, hypoxia-inducible factor $1 \alpha$; Nrf2, nuclear factor erythroid-2-related factor 2

Key words: heme oxygenase-1, skin flap, heat shock protein, carbon monoxide, preconditioning

\section{Contents}

1. Introduction

2. Biological characteristics of HO-1

3. HO-1-mediated enzymatic cascades and the functional significance of its products

4. Protective effects of HO-1 on skin flaps

5. Perspectives

\section{Introduction}

In the fields of plastic surgery, hand and foot surgery, and burn treatment, skin flaps are particularly important for the closure of tissue defects. However, the ability to attenuate or even abolish the necrosis that occurs on skin flaps, mainly due to ischemia, remains challenging. Necrosis of the skin flap is not only related to anatomical factors of the skin flap itself (1-3), but also to some high-risk factors of the patient, such as age and diabetes (4-7). For example, Las et al (8) reported that diabetes, excessive anesthesia time and postoperative wound infection are risk factors for the failure of free flaps. Bekara et al (5) showed that an age older than 60 years, or the presence of diabetes and arterial diseases are risk factors for complications of lower extremity pedicle perforator flaps. In addition, Sanati-Mehrizy et al (4) reported that smoking and operation time are risk factors for free flap necrosis and de Blacam et al (7) found that venous congestion and increased age are risk factors for pedicle flap failure. Current literature regarding the risk factors of skin flap necrosis mainly focus on free skin flaps and lower limb pedicled skin flaps (8-15), and treatment methods that have been proposed are based on various mechanisms such as surgical delay, chemical delay, extracorporeal shock wave therapy, local thermal pretreatment, percutaneous neuroelectric pretreatment, cold pretreatment, negative pressure suction, targeted gene therapy, and drug injection (16-25). Heat shock proteins (Hsps), which are highly evolutionarily conserved from prokaryotes to human (26), are molecular chaperons that exhibit a variety of biological activities including anti-oxidative, anti-apoptotic and anti-inflammatory effects (27). In recent years, several Hsps have been shown to prevent skin flap necrosis by reducing inflammation, oxidative stress, apoptosis and regulating platelet activity (28-32). 
Hsp32, a member of the Hsp family also known as heme oxygenase (HO)-1, is the most commonly studied molecule in the HO family of proteins. However, clinical data concerning HO-1 in flap surgery are scarce. This review summarizes the biological characteristics of HO-1 and the functional significance of its products. In particular, this review focuses on the role of carbon monoxide $(\mathrm{CO})$, one of the primary metabolites of HO-1, in flap survival, elaborates on the protective effect of HO-1 on skin flaps (Table I), and discusses the feasibility and existing challenges of HO-1 in flap surgery.

\section{Biological characteristics of HO-1}

The human $H O-1$ gene, located on chromosome $22 \mathrm{q} 12$, is approximately $1414 \mathrm{~kb}$ in length and contains four introns and five exons. The length of the (GT)n microsatellite structure is unique to the promoter region of the human $\mathrm{HO}-1$ gene and affects its transcription. A longer (GT)n leads to more GT dinucleotide sequence repeats and decreased $\mathrm{HO}-1$ gene transcription and expression levels (33).

The HO family consists of three members: HO-1, HO-2 and HO-3. HO-1 is the rate-limiting enzyme of heme metabolism (34), but the functions of $\mathrm{HO}-2$ and $\mathrm{HO}-3$ remain elusive. $\mathrm{HO}-1$, with a molecular weight of $32 \mathrm{kDa}$, is a stress protein that is either not expressed or has exceptionally low expression under normal conditions. However, HO-1 can be induced by a variety of stimuli, including heavy metals, heat shock, inflammatory stimuli, heme and its derivatives, stress, hypoxia, and biological hormones (35-39). Increased HO-1 expression under stress reduces protein oxidation and lipid peroxidation, and attenuates cell and blood vessel damage, thus playing a protective role $(40,41)$. For instance, Chen et al (40) reported that stress significantly increases $\mathrm{HO}-1$ expression in the heart, which in turn provides cardioprotection. On the other hand, most metalloporphyrins, including tin protoporphyrin and zinc protoporphyrin, are inhibitors of HO-1 and compete with heme for the HO-1 binding site, thereby inhibiting the biological effects of HO-1 $(42,43)$. The molecular weights of $\mathrm{HO}-2$ and $\mathrm{HO}-3$ are $36 \mathrm{kDa}$ and $33 \mathrm{kDa}$, respectively (44). It is known that adrenal cortex hormones can induce the expression of HO-2, and it is therefore speculated that $\mathrm{HO}-2$ can regulate functions within the nervous system. HO-3 has $90 \%$ primary structure homology with $\mathrm{HO}-2$ but does not have any enzymatic activity. It is speculated that HO-3 regulates heme-dependent functions within cells (45).

\section{HO-1-mediated enzymatic cascades and the functional significance of its products}

HO-1 exists in microsomes and is the rate-limiting enzyme for heme catabolism, which splits heme into biliverdin, $\mathrm{CO}$ and iron. Biliverdin is further reduced to bilirubin under the action of biliverdin reductase, which is an effective anti-oxidant that protects cells from oxidative stress $(46,47)$. Another metabolite, $\mathrm{CO}$, acts on soluble guanylate cyclase (sGC) to increase the production of cyclic guanosine monophosphate (cGMP), which serves as a second messenger to regulate a wide spectrum of cellular events, including vasodilation $(48,49)$ as well as anti-inflammatory and anti-apoptotic activities (50) (Fig. 1).
Heme. Heme is a pro-oxidant molecule that participates in the formation of oxidative free radicals leading to oxidative damage (51). In a model of heme overload using nude mice, excessive heme in the plasma promotes the production of reactive oxygen species (ROS) and reduces the effectiveness of nitric oxide (NO), thereby affecting the expansion of blood vessels (52). HO-1 degrades heme, and therefore has anti-oxidant activity. Balla et al (51) showed that the combination of heme and ferritin, together with HO-1, prevents oxidative stress. In another study performed in cultured alveolar epithelial cells, HO-1 overexpression was found to lead to a nearly 3-fold increase in ferritin, which was accompanied by a compensatory increase in transferrin receptors, subsequently altering the distribution of iron in the cells and protecting cells from iron toxicity induced by heme degradation (53).

CO anti-inflammatory activity. The anti-inflammatory activity of $\mathrm{CO}$ and $\mathrm{CO}$-releasing molecules (CORM) has been well documented in various animal models. Increased HO-1 expression or $\mathrm{CO}$ prevents impairment of the blood-brain barrier (BBB), cerebral microvascular congestion and neuroinflammation (54). Mechanistically, this protection is achieved by the binding of $\mathrm{CO}$ to hemoglobin to prevent its oxidation and the production of free hemoglobin (54). In addition, a carrageenan-induced inflammation model showed that $\mathrm{CO}$ inhibits neutrophil migration and white blood cell adhesion (55). On the other hand, CORM-2 reduces the accumulation of inflammatory cells, the expression of intercellular adhesion molecule-1 (ICAM-1) and the activation of nuclear factor $\kappa \mathrm{B}(\mathrm{NF}-\kappa \mathrm{B})$ in septic mice (56). In vitro experimental study confirmed that the mechanisms behind the anti-inflammatory effect of CORM-2 are related to the decreased expression of NF- $\kappa \mathrm{B}$-dependent vascular endothelial cell adhesion molecules and secretion of inducible nitric oxide synthase (iNOS) (56). Using an animal model related to human sepsis (cecal ligation and puncture in rodents), CORM-2 or CORM-3 was found to reduce the migration of polymorphonuclear (PMN) leukocytes to purulent tissues, thereby attenuating inflammation and saving animals from succumbing to sepsis (57-59). In HO-1-deficient mice, treatment with CORM-2 was found to ameliorate the severity of sepsis associated with Enterococcus faecalis infection (60). CORM-3 was found to have a bactericidal effect on Pseudomonas aeruginosa, thereby reducing the mortality of mice with bacteremia (61). Additionally, CO exerts prominent anti-inflammatory actions in part by reducing the release of tumor necrosis factor $\alpha(\mathrm{TNF}-\alpha)$, interleukin (IL)-1, macrophage inflammatory protein (MIP)-1 and IL-6 from activated macrophages $(62,63)$.

Protective effect of $\mathrm{CO}$ in cardiovascular diseases. The beneficial effects of $\mathrm{CO}$ on the cardiovascular system have been gradually discovered. Due to severe arterial thrombosis, HO-1-deficient mice died within four days following an aortic transplantation; however, treatment with CORM-2 was found to improve the survival rate of HO-1-deficient mice (64). The underlying protective mechanisms are related to the inhibition of platelet aggregation through the activation of guanylate cyclase (65). Endogenous 


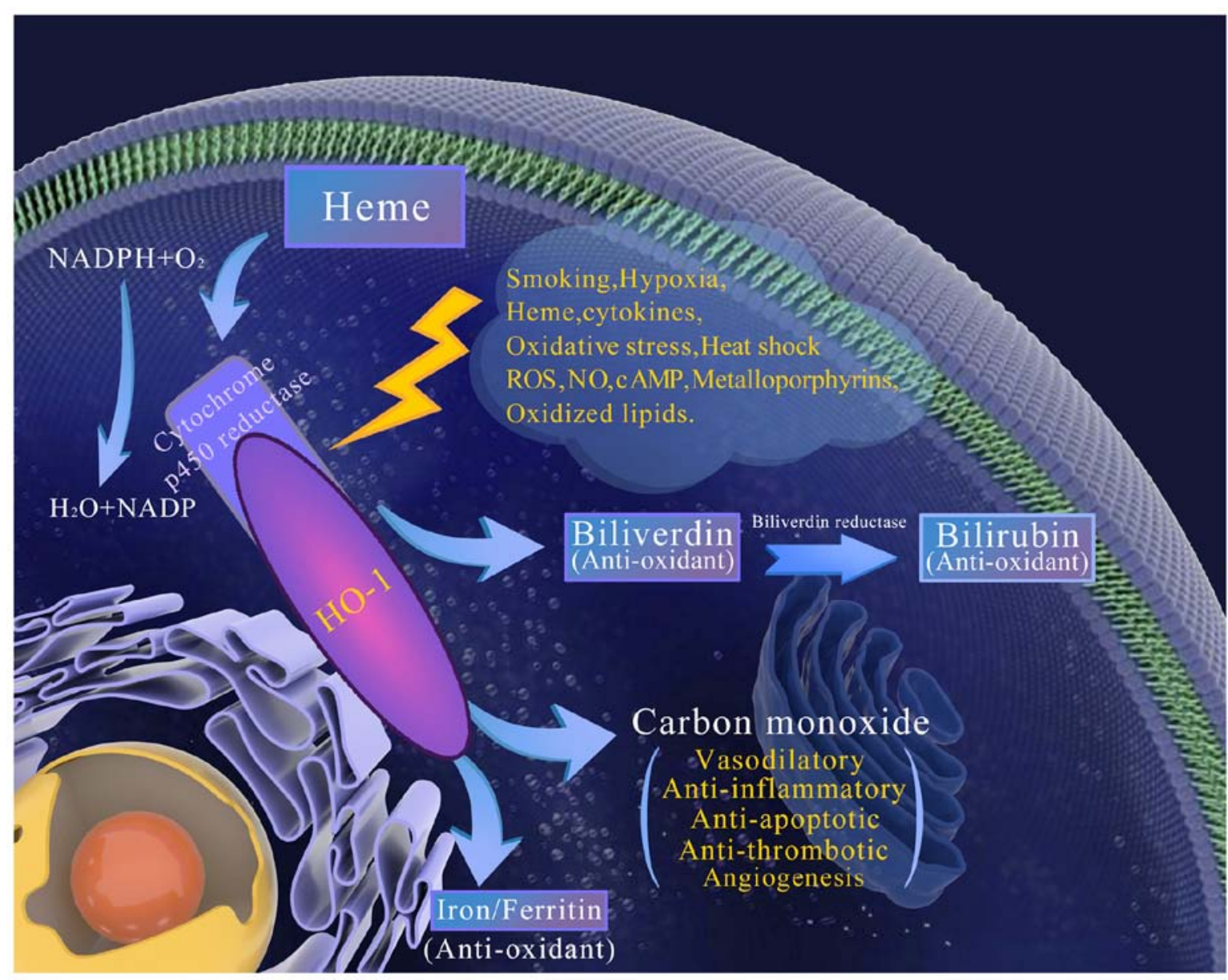

Figure 1. Biological activities of HO-1 and its byproducts. A variety of stimuli can produce HO-1, which in turn degrades the pro-oxidant heme, and produce effective anti-oxidant molecules, bile pigments and vasodilator carbon monoxide (CO) molecules. HO-1, heme oxygenase-1; ROS, reactive oxygen species.

$\mathrm{CO}$ binds to and activates $\mathrm{sGC}$, subsequently increasing the concentration of cGMP and inducing a vasodilatory response $(50,66)$. In a mouse model of myocardial infarction caused by coronary artery ligation, intravenous infusion of CORM-3 prior to reperfusion was found to reduce infarct size, fibrillation and tachycardia $(67,68)$. The mechanisms underlying CORM-3-mediated cardiovascular protection involve potassium channels, since a small amount of CORM-3 is lost when mitochondrial ATP-dependent potassium channel inhibitors are used $(67,68)$. Another study also demonstrated that HO-1 promotes angiogenesis through CO (69), and improves the survival of tissues surrounding the blood supply by inhibiting apoptosis of endothelial cells (70).

Preservation of transplanted organs. Many scholars have reported that $\mathrm{CO}$ plays an important role in organ transplantation and preservation. $\mathrm{CO}$ in a gaseous form or as a CORM can be used as a preservation adjuvant in organ preservation solution. Using a model of allogeneic heart transplantation in rodents, continuous inhalation of $\mathrm{CO}$ or CORM can prolong the survival time of the transplanted heart $(71,72)$. The cardioprotective effect of $\mathrm{CO}$ gas is achieved by inhibiting platelet aggregation and endothelial cell apoptosis, as well as producing endogenous vasoconstrictors, thereby improving the microcirculation of the graft $(71,72)$. Compared with the untreated control group, rabbit kidneys washed with CORM-3 or CORM-1 and then stored in a cold solution for $24 \mathrm{~h}$ showed higher rates of perfusion flow, glomerular filtration, and sodium and glucose reabsorption (73). The above-mentioned mechanisms of renal protection are thought to be related to $\mathrm{CO}$-medicated expansion of blood vessels, inhibition of cell apoptosis and promotion of angiogenesis (73).

Bilirubin and biliverdin. As previously mentioned, HO-1 generates biliverdin, which is then converted to bilirubin. Both bilirubin and biliverdin are effective oxidative inhibitors (74). Human biliverdin reductase (hBVR), a Ser/Thr/Tyr kinase, is activated by insulin and free radicals (75). hBVR is central to the activation as well as the nuclear import and export of extracellular signal-regulated kinase (ERK)1/2 (76). Insulin increases BVR tyrosine phosphorylation and increases glucose uptake when BVR is knocked down by small interfering RNA, suggesting an important function of BVR in insulin signaling (77). HO-1-derived bilirubin is an efficient scavenger of reactive oxygen and nitrogen species (RONS) (78). In macrophages, biliverdin induces the phosphorylation of endothelial NO synthase (eNOS) at Ser1177, which generates eNOS. It is well recognized that NO plays a crucial role in regulating a wide spectrum of vascular functions, including vasorelaxation, inhibition of leukocyte-endothelial adhesion, 
vascular smooth muscle cell migration and proliferation, and platelet aggregation (79).

In summary, each product generated by HO-1 plays an important role in protecting cells and tissues through a variety of mechanisms.

\section{Protective effects of HO-1 on skin flaps}

Anti-inflammatory effect. The survival rate of skin flaps is related to ischemia-reperfusion injury and surgical trauma. Ischemia-reperfusion injury, if not treated in a timely and appropriate manner, may cause unfavorable outcomes for patients. Both surgical trauma and ischemia-reperfusion may initiate inflammatory responses, causing white blood cells to roll and adhere to the capillary vein (80-82). In the early reperfusion phase, the accumulation of activated leukocytes and reactive oxygen metabolites aggravates the inflammatory response and ultimately impairs endothelial integrity (83). The initiation of the stress response leads to increased HO-1, which significantly reduces the adhesion of white blood cells to the endothelial surface and lessens the impairment of the integrity of venous endothelium (84). Rücker et al (84) studied whether stress conditioning-induced HO-1 could prevent an inflammatory response in transferred osteomyocutaneous flaps. In all tissues analyzed, control flaps presented with significant leukocyte adherence in postcapillary venules, increased expression of intercellular adhesion molecule-1 (ICAM-1), and disruption of endothelial integrity. In contrast, stress conditioning induced considerable $\mathrm{HO}-1$ expression, which coincided with a significant reduction of leukocyte adherence, ICAM-1 expression, and endothelial hyperpermeability. Correspondingly, the inhibition of HO-1 by tin protoporphyrin IX completely abolished the stress conditioning-induced amelioration of the inflammatory response (84). Hence, the protective effect elicited by stress conditioning is mainly mediated by the induction of HO-1, which reduces oxygen free radicals, ICAM-1, adherence of white blood cells to the endothelial surface, endothelial permeability and macromolecular extravasation, ultimately reducing the overall inflammatory response.

Anti-oxidative effect. Rats undergoing flap reconstruction surgery experience lipid peroxidation and vascular damage, which is related to ischemia-reperfusion injury (85). Ischemia-reperfusion injury involves a complex oxidation process, which is closely related to flap survival (86). Oxidative stress induces an excessive activation of inflammatory processes, which increases ROS. ROS are molecules known to cause tissue damage through multiple mechanisms, including altering the structure and chemistry of proteins, lipids, and nucleic acids. Hence, reducing the release of ROS or removing excessive ROS protects tissues from ischemia-reperfusion injury (87). Lin et al (88) reported that CORM-2 induces HO-1 expression, thereby reducing protein kinase $\mathrm{C}(\mathrm{PKC}) / \mathrm{amino}$ acid-rich tyrosine kinase 2 (Pyk2)-dependent production of ROS. Lin et al (28) showed that ginkgolide B reduced skin flap necrosis and improved the survival of island perforator flaps by inhibiting endoplasmic reticulum stress and oxidative stress. In this study, they further showed that ginkgolide B activated nuclear factor erythroid 2-related factor 2 (Nrf2) signaling. Following its activation, Nrf2 is transported to the nucleus, where it binds to antioxidant response elements located in the cis-regulatory sequences of antioxidant-related enzymes and proteins and increases their expression (89).

Anti-apoptosis, vasodilation and angiogenesis. Brouard et al (90) studied the anti-apoptotic potential of HO-1 in cultured endothelial cells and found that $\mathrm{CO}$, the product of heme digested by HO-1, activates the p38 mitogen-activated protein kinase (MAPK) pathway to inhibit endothelial cell apoptosis. But the HO-1 agonist heme arginate (HA) failed to improve the survival rate of ischemic flaps (91). In vitro studies have shown that HA is cytotoxic to keratinocytes (91). Brouard et al (90) also found that $\mathrm{CO}$ causes vasodilation, which is part of the mechanism by which HO-1 protects skin flaps from chronic ischemia-induced injury (90). Chronic ischemia was found to increase the expression of $\mathrm{HO}-1$, especially on the first and third days post-operation. Increased HO-1 expression in turn induces arteriole expansion and promotes perfusion, which can maintain sufficient capillary perfusion density in the flap and reduce flap necrosis (92). The inhibition of endogenous HO-1 by tin protoporphyrin IX was found to completely eliminate arteriole expansion and hyperperfusion, resulting in a significant decrease in functional capillary density, a significant increase in cell apoptosis, and skin flap necrosis, but aging can reverse this protective effect (92-94). Consistent with the above findings, Kubulus et al (95) reported that delay-associated tissue protection can be obtained by HO-1-mediated attenuation of microcirculatory dysfunction. Increased HO-1 activity protects tissues by biliverdin-associated anti-oxidative actions and/or CO-mediated vasodilation. This is supported by findings that show that trolox treatment after selective blockade of HO-1 reduced necrosis only until day three after flap creation and did not affect the manifestation of microcirculatory disorders. These observations suggested that: i) oxidative stress contributes to the initial development of flap necrosis; ii) anti-oxidative treatment counteracts oxidative stress-induced cell damage; iii) the initial oxidative stress does not define the degree or severity of final flap necrosis; and iv) HO-1 prevents flap necrosis induced by chronic ischemic conditioning (delay) primarily through its vasodilatory action and by improving microvascular perfusion (95). Kubulus et al (23) further showed that cooling induced a marked expression of HO-1 without induction of the Hsp70 protein, which was accompanied by significant improvement in microvascular perfusion. Thus, HO-1 also plays a role in the cooling-mediated amelioration of microcirculation, which results in a significant reduction in final flap necrosis. In another independent study, Sun et al (96) showed that preconditioning with isoflurane promotes hypoxic stabilization and induces the accumulation of hypoxia-inducible factor $1 \alpha$ (HIF-1 $\alpha$ ), while HIF-1 $\alpha$ mediates transcriptional activation of the HO-1 gene in response to hypoxia to induce angiogenesis.

However, research has also shown that $\mathrm{HO}-1$ may have dual functions. For example, HO-1 has a dual role in cancer cells. The levels of cellular iron and ROS are the determining factors for the role of HO-1, in which excessive cellular iron and ROS tend to push HO-1 from a protective 
Table I. Summary of the literature regarding Hsp32 application in the field of flap surgery.

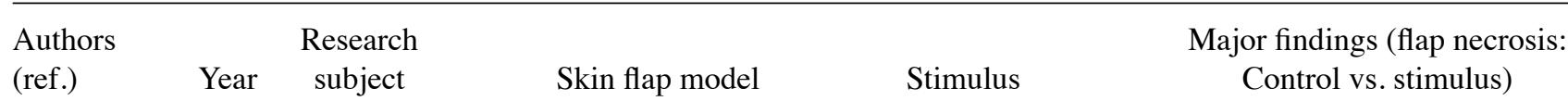

\begin{tabular}{|c|c|c|c|c|c|}
\hline $\begin{array}{l}\text { Rücker } \\
\text { et al (36) }\end{array}$ & 2001 & Rat & $\begin{array}{l}\text { Osteomyocutaneous } \\
\text { flaps of left hindlimb }\end{array}$ & Local heat-shock & $\begin{array}{l}\text { Stress initiated by local heat shock } \\
\text { improved nutrient perfusion of the } \\
\text { musculocutaneous flap through } \\
\text { HO-1-elicited capillary dilation. }\end{array}$ \\
\hline
\end{tabular}

\begin{tabular}{|c|c|c|}
\hline $\begin{array}{l}\text { Rücker } \\
\text { et al (84) }\end{array}$ & $2001 \quad$ Rat & $\begin{array}{l}\text { Osteomyocutaneous } \\
\text { flaps of left hindlimb }\end{array}$ \\
\hline
\end{tabular}

Local heat-shock

Local heat shock-induced stress increased HO-1 expression in musculocutaneous flaps, which was related to a significant decrease in leukocyte adhesion, ICAM-1 expression and high endothelial permeability. Hsp32 inhibitors completely abolished the anti-inflammatory effect of HO-1. These observations suggest that local heat shock-initiated stress can reduce the inflammatory response of the musculocutaneous flap.

$\begin{array}{lllll}\begin{array}{l}\text { Harder } \\ \text { et al }(93)\end{array} & 2004 & \text { Pig } & \begin{array}{l}\text { A random-pattern skin } \\ \text { flap was collected } \\ \text { on both sides of the } \\ \text { buttocks }\end{array} & \begin{array}{l}\text { Local heat } \\ \text { preconditioning }\end{array} \\ \begin{array}{l}\text { Kubulus } \\ \text { et al }(95)\end{array} & 2004 & \text { Mouse } & \begin{array}{l}\text { Axial-pattern skin flap } \\ \text { of the ear }\end{array} & \text { Surgical delay }\end{array}$

Local heat preconditioning significantly reduced ischemic flap necrosis by decreasing complications of ischemia-related wound healing ( $40 \pm 8$ vs. $7 \pm 14 \%, \mathrm{P}<0.01$ ). Overall protection against flap necrosis by chronic ischemic conditioning (delay) was mediated by HO-1, not through an anti-oxidative function but rather through a vasodilatory action, which prevented microvascular perfusion failure $(41 \pm 3$ vs. $16 \pm 3 \%, \mathrm{P}<0.05)$.

$\begin{array}{llll}\begin{array}{l}\text { Harder } \\ \text { et al }(34)\end{array} & 2005 & \text { Mouse } & \begin{array}{l}\text { A random-pattern } \\ \text { myocutaneous flap was } \\ \text { collected on the back }\end{array}\end{array}$

Local heat preconditioning of myocutaneous tissue markedly increased flap survival by maintaining adequate nutrient perfusion rather than inducing ischemic tolerance $(53 \pm 5$ vs. $4 \pm 1 \%$, $\mathrm{P}<0.001)$.

\begin{tabular}{|c|c|c|c|}
\hline $\begin{array}{l}\text { Chang } \\
\text { et al (37) }\end{array}$ & 2005 & Human & $\begin{array}{l}\text { Gingival fibroblasts and } \\
\text { tissues were obtained } \\
\text { from cigarette smokers } \\
\text { and non-smokers }\end{array}$ \\
\hline
\end{tabular}

Nicotine

The expression of HO-1 in gingival tissues of smokers was significantly upregulated; nicotine and other components may be a reason for the increased expression of HO-1. Regulation of nicotine-induced HO-1 expression was heavily dependent on the intracellular concentration of GSH.

\begin{tabular}{|c|c|c|c|}
\hline $\begin{array}{l}\text { Kubulus } \\
\text { et al (23) }\end{array}$ & 2005 & Mouse & $\begin{array}{l}\text { Axial-pattern skin flap } \\
\text { of the ear }\end{array}$ \\
\hline
\end{tabular}

Cold pretreatment induced significant expression of HO-1, but not Hsp70 protein. HO-1 induced capillary dilation, thereby improving microvascular perfusion.

$\begin{array}{llll}\begin{array}{l}\text { Harder } \\ \text { et al }(94)\end{array} & 2007 \quad \text { Mouse } & \begin{array}{l}\text { Axial-pattern skin flap } \\ \text { of the ear }\end{array} & \text { Aging }\end{array}$

The increased susceptibility to ischemic necrosis during aging is more likely due to a loss of vascular reactivity to endogenous $\mathrm{HO}-1$, resulting in a lack of adequate adaptation to chronically ischemic conditions [49 $\pm 8 \%(\mathrm{P}<0.05)$ and $42 \pm 8 \%(\mathrm{P}<0.05)$ in aging and adult patients, compared with $31 \pm 6 \%$ in young patients]. 
Table I. Continued.

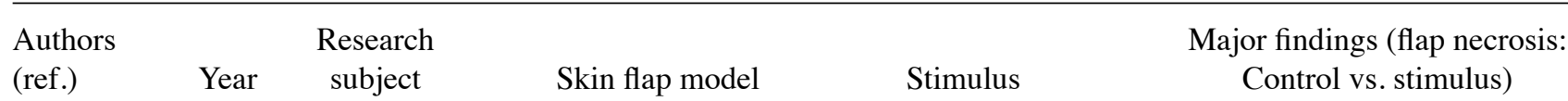

\begin{tabular}{|c|c|c|c|c|}
\hline $\begin{array}{l}\text { Contaldo } \\
\text { et al (38) }\end{array}$ & 2007 & Pig & $\begin{array}{l}\text { A random-pattern skin } \\
\text { flap was raised on both } \\
\text { sides of the buttocks }\end{array}$ & $\begin{array}{l}\text { MPL and local } \\
\text { hyperthermia }\end{array}$ \\
\hline
\end{tabular}

\begin{tabular}{|c|c|c|c|}
\hline $\begin{array}{l}\text { Harder } \\
\text { et al (92) }\end{array}$ & 2008 & Mouse & Random flap on the back \\
\hline
\end{tabular}

Schürmann 2009 Mouse et al (39)

Caudally pedicled skin flap on the back
2013 Human cells Random-pattern skin and rat flaps on back

$\begin{array}{llll}\begin{array}{l}\text { Sun } \\ \text { et al (96) }\end{array} & 2013 & \begin{array}{l}\text { Human cells } \\ \text { and rat }\end{array} & \begin{array}{l}\text { Random-pattern skin } \\ \text { flaps on back }\end{array} \\ \text { Edmunds } & 2014 & \begin{array}{l}\text { Rat and } \\ \text { human } \\ \text { et al (91) }\end{array} & \begin{array}{l}\text { A transverse rectus } \\ \text { abdominismyocutaneous } \\ \text { keratinocytes } \\ \text { flaks })\end{array} \\ & & \end{array}$

Han 2015 Rat

et al (86)

Lin $2019 \quad$ Rat
et al $(28)$

Abdominal rectangular ADSCs
random flap

Multiterritory perforator GB

flap on the back
iNOS and HO-1 were upregulated after MPL and local hyperthermia $(\mathrm{P}<0.05)$, but only local hyperthermia significantly reduced the necrosis rate of skin flaps [44\% in local hyperthermia, compared with $29 \%$ in control $(\mathrm{P}<0.05)]$.

Chronic ischemia-induced endogenous $\mathrm{HO}-1$ protected ischemic tissues through the vasodilatory action of HO-1-associated $\mathrm{CO}$ release $(73 \pm 5$ vs. $51 \pm 5 \%, \mathrm{P}<0.001)$.

Surgery of a caudally-based skin flap

ISO

Skin flap epithelial keratinocytes presented a prominent inflammatory response upon surgery, which was not amplified but rather controlled by invading HO-1 expressing-macrophages in the surviving flap tissues.

ISO preconditioning improved survival of skin flaps by upregulating the expression of HIF- $1 \alpha, \mathrm{HO}-1$ and VEGF $(51.5 \pm 5.6$ vs. $43.3 \pm 6.7 \%, \mathrm{P}<0.05)$.

HA Compared with the control group, the HO-1 agonist HA failed to improve the survival rate of ischemic flaps (Compared with the control group, skin flap necrosis was more than $30 \%$ higher in HO-1 agonist HA group; $\mathrm{P}=0.002$ ). In vitro studies have shown that HA is cytotoxic to keratinocytes.

Adjuvant treatment with ADSCs significantly increased the survival of a skin flap in the venous ischemia-reperfusion condition.

This effect was achieved through the suppression of the inflammatory response and induction of the antioxidative response (68.7 \pm 11.9 vs. $48.4 \pm 13.6 \%$, $\mathrm{P}<0.05)$.

GB reduced oxidative stress through the activation of Nrf2/HO-1 signaling and enhancement of antioxidant activity $(37.03 \pm 6.50$ vs. $9.17 \pm 1.93 \%, \mathrm{P}<0.01)$.

Hsp, heat shock protein; HO-1, heme oxygenase-1; ICAM-1, intercellular adhesion molecule-1; GSH, glutathione; iNOS, inducible nitric oxide synthase; MPL, ministration of monophosphoryl lipid A; HIF-1 $\alpha$, hypoxia-inducible factor 1 $\alpha$; VEGF, vascular endothelial growth factor; HA, hemearginate; ISO, isoflurane; HA, heme arginate; ADSCs, adipose-derived stem cells; GB, ginkgolide B; Nrf2, nuclear factor erythroid-2-related factor 2 .

role to that of a perpetrator. In general, a moderate level of HO-1 activation exerts a cytoprotective effect, while the over-activation of HO- 1 becomes cytotoxic due to the excessive increase of labile $\mathrm{Fe}^{2+}$ behind the buffering capacity of ferritin (97). Similarly, HO-1 also has a dual role in nerve cells. Nrf2-dependent activation of HO-1 is 
generally linked to protective effects in neurons and glial cells, while Nrf2-independent activation of HO-1, which often involves AP-1 or NF- $\mathrm{BB}$, seems to exert neurotoxic effects. Indeed, HO-1 expression is associated with neuronal damage and neurodegeneration, especially in Alzheimer's and Parkinson's disease (98).

The application of $\mathrm{CO}$, the catalytic product of $\mathrm{HO}-1$, within a clinical setting also has the following issues. For example, the safety constraints of $\mathrm{CO}$ require clinical dosing to maintain levels of carboxyhemoglobin $(\mathrm{CO}-\mathrm{Hb})$ that are under $14 \%$, which is in stark contrast to the preclinical frontrunner studies with protocols that had sustained CO-Hb levels above 20\% (99). Also, the pharmacokinetics of $\mathrm{CO}$ inhalation protocols varied significantly by species. Rodent models achieve therapeutic levels quickly, whereas the time to steady state in humans is roughly three times longer based on respiratory rate and cardiac output (100).

Similarly, the application of HO-1 or its metabolites to the field of flap surgery will also face the above-mentioned issues. Instead, perhaps it would be possible to: i) use HO-1 inhibitors (such as tin protoporphyrin) to repress its overexpression; ii) use an occasional monitoring system to achieve feedback to control the level of $\mathrm{CO}$ in the body; or iii) search for molecules that promote the release of $\mathrm{CO}$ or solutions that can dissolve $\mathrm{CO}$, and apply them locally to reduce systemic adverse reactions.

\section{Perspectives}

HO-1 was first described in the late 1960s and its functions have been gradually characterized over the following decades, innovative observations have been made over the past 20 years uncovering the cellular cytoprotective capability of HO-1 in a clinical setting. While studies have defined to some degree the tissue protective roles of each of the by-products generated by HO-1 (including $\mathrm{CO}$ ) and attempted to harness $\mathrm{HO}-1$ to improve $\mathrm{CO}$-delivery for clinical applications, there are still significant limitations that prevent its use at the bed side (99). Previous studies have shown the clinical relevance of HO-1, such as in ischemic stroke (101), skin health (102) and cardiovascular syndromes and co-morbidities (103). However, there are few studies on the application of HO-1 in the field of human flap surgery. How to direct the clinical application of HO-1 and its related products in the field of flap surgery in order to obtain more appreciable outcomes will be the focus of future research.

\section{Acknowledgements}

The authors would like to thanks Dr Huanfa Yi from the Second Department of the First Hospital of Jilin University, who provided critical comments and invaluable advice on this manuscript.

\section{Funding}

No funding was received.

\section{Availability of data and materials}

Not applicable.

\section{Authors' contributions}

YZ drafted the manuscript. ZL assisted with the literature search. MY assisted with drafting and revising the manuscript. XG conceived and designed the review. YZ and XG are responsible for confirming the authenticity of the raw data. All authors read and approved the final manuscript and agree to be accountable for the accuracy and referencing of the information included in the review.

\section{Ethics approval and consent to participate}

Not applicable.

\section{Patient consent for publication}

Not applicable.

\section{Competing interests}

The authors declare that they have no competing interests.

\section{References}

1. Taylor GI, Corlett RJ, Dhar SC and Ashton MW: The anatomical (angiosome) and clinical territories of cutaneous perforating arteries: Development of the concept and designing safe flaps. Plast Reconstr Surg 127: 1447-1459, 2011.

2. Saint-Cyr M, Wong C, Schaverien M, Mojallal A and Rohrich RJ: The perforasome theory: Vascular anatomy and clinical implications. Plast Reconstr Surg 124: 1529-1544, 2009.

3. Callegari PR, Taylor GI, Caddy CM and Minabe T: An anatomic review of the delay phenomenon: I. Experimental studies. Plast Reconstr Surg 89: 397-407; discussion 417-398, 1992.

4. Sanati-Mehrizy P, Massenburg BB, Rozehnal JM,Ingargiola MJ, Hernandez Rosa J and Taub PJ: Risk factors leading to free flap failure: Analysis from the national surgical quality improvement program database. J Craniofac Surg 27: 1956-1964, 2016.

5. Bekara F, Herlin C, Mojallal A, Sinna R, Ayestaray B, Letois F, Chavoin JP, Garrido I, Grolleau JL and Chaput B: A systematic review and meta-analysis of perforator-pedicled propeller flaps in lower extremity defects: Identification of risk factors for complications. Plast Reconstr Surg 137: 314-331, 2016.

6. Wong AK, Joanna Nguyen T, Peric M, Shahabi A, Vidar EN, Hwang BH, Niknam Leilabadi S, Chan LS and Urata MM: Analysis of risk factors associated with microvascular free flap failure using a multi-institutional database. Microsurgery 35 : 6-12, 2015.

7. de Blacam C, Colakoglu S, Ogunleye AA, Nguyen JT, Ibrahim AM, Lin SJ, Kim PS and Lee BT: Risk factors associated with complications in lower-extremity reconstruction with the distally based sural flap: A systematic review and pooled analysis. J Plast Reconstr Aesthet Surg 67: 607-616, 2014.

8. Las DE, de Jong T, Zuidam JM, Verweij NM, Hovius SE and Mureau MA: Identification of independent risk factors for flap failure: A retrospective analysis of 1530 free flaps for breast, head and neck and extremity reconstruction. J Plast Reconstr Aesthet Surg 69: 894-906, 2016.

9. Li B, Chang SM, Du SC, Zhuang L and Hu SJ: Distally based sural adipofascial turnover flap for coverage of complicated wound in the foot and ankle region. Ann Plast Surg 84: 580-587, 2020.

10. Lee ZH, Abdou SA, Ramly EP, Daar DA, Stranix JT, Anzai L, Saadeh PB, Levine JP and Thanik VD: Larger free flap size is associated with increased complications in lower extremity trauma reconstruction. Microsurgery 40: 473-478, 2020.

11. Stranix JT, Lee ZH, Anzai L, Jacoby A, Avraham T, Saadeh PB, Levine JP and Thanik VD: Optimizing venous outflow in reconstruction of Gustilo IIIB lower extremity traumas with soft tissue free flap coverage: Are two veins better than one? Microsurgery 38: 745-751, 2018. 
12. Gupta A, Lakhiani C, Lim BH, Aho JM, Goodwin A, Tregaskiss A, Lee M, Scheker L and Saint-Cyr M: Free tissue transfer to the traumatized upper extremity: Risk factors for postoperative complications in 282 cases. J Plast Reconstr Aesthet Surg 68: 1184-1190, 2015.

13. Reece EM, Bonelli MA, Livingston T, Mulligan PS, Rockwood J, Wilson JR, Zoldos J and Champagne L: Factors in free fasciocutaneous flap complications: A logistic regression analysis. Plast Reconstr Surg 136: 54e-58e, 2015.

14. Innocenti M, Menichini G, Baldrighi C, Delcroix L, Vignini L and Tos P: Are there risk factors for complications of perforator-based propeller flaps for lower-extremity reconstruction? Clin Orthop Relat Res 472: 2276-2286, 2014

15. Dolan RT, Butler JS, Murphy SM and Cronin KJ: Health-related quality of life, surgical and aesthetic outcomes following microvascular free flap reconstructions: An 8-year institutional review. Ann R Coll Surg Engl 94: 43-51, 2012.

16. Ellabban MA, Fattah IOA, Kader GA, Eldeen OS, Mehana AE, Khodeer DM, Hosny H, Elbasiouny MS and Masadeh S: The effects of sildenafil and/or nitroglycerin on random-pattern skin flaps after nicotine application in rats. Sci Rep 10: 3212, 2020.

17. Lee W, Oh W, Oh SM and Yang EJ: Comparative effectiveness of different interventions of perivascular hyaluronidase. Plast Reconstr Surg 145: 957-964, 2020.

18. Giatsidis G, Cheng L, Haddad A, Ji K, Succar J, Lancerotto L, Lujan-Hernandez J, Fiorina P, Matsumine H and Orgill DP: Noninvasive induction of angiogenesis in tissues by external suction: Sequential optimization for use in reconstructive surgery. Angiogenesis 21: 61-78, 2018.

19. Giatsidis G, Cheng L, Facchin F, Haddad A, Lujan-Hernandez J, Lancerotto L, Nabzdyk CG, Matsumine $\mathrm{H}$ and Orgill DP Moderate-intensity intermittent external volume expansion optimizes the soft-tissue response in a murine model. Plast Reconstr Surg 139: 882-890, 2017.

20. Doğan F and Özyazgan İ: Flap preconditioning by electrical stimulation as an alternative to surgical delay: Experimental study. Ann Plast Surg 75: 560-564, 2015.

21. Menevşe GT, TeomanTellioglu A, Altuntas N, Cömert A and Tekdemir I: Polidocanol injection for chemical delay and its effect on the survival of rat dorsal skin flaps. J Plast Reconstr Aesthet Surg 67: 851-856, 2014.

22. Tobalem M, Wettstein R, Pittet-Cuénod B, Vigato E, Machens HG, Lohmeyer JA, Rezaeian F and Harder Y: Local shockwave-induced capillary recruitment improves survival of musculocutaneous flaps. J Surg Res 184: 1196-1204, 2013.

23. Kubulus D, Amon M, Roesken F, Rücker M, Bauer I and Menger MD: Experimental cooling-induced preconditioning attenuates skin flap failure. Br J Surg 92: 1432-1438, 2005.

24. Morris SF and Taylor GI: The time sequence of the delay phenomenon: When is a surgical delay effective? An experimental study. Plast Reconstr Surg 95: 526-533, 1995.

25. Akimoto M, Takeda A, Matsushita O, Inoue J, Sakamoto K, Hattori M, Kounoike N and Uchinuma E: Effects of CB-VEGF-A injection in rat flap models for improved survival. Plast Reconstr Surg 131: 717-725, 2013.

26. Lindquist $\mathrm{S}$ and Craig EA: The heat-shock proteins. Annu Rev Genet 22: 631-677, 1988.

27. Miller DJ and Fort PE: Heat shock proteins regulatory role in neurodevelopment. Front Neurosci 12: 821, 2018.

28. Lin D, Wu H, Zhou Z, Tao Z, Jia T and Gao W: Ginkgolide B improves multiterritory perforator flap survival by inhibiting endoplasmic reticulum stress and oxidative stress. J Invest Surg: 1-7, Dec 23, 2019 (Epub ahead of print).

29. Kumar D, Jena GR, Ram M, Lingaraju MC, Singh V, Prasad R, Kumawat S, Kant V, Gupta P, Tandan SK and Kumar D: Hemin attenuated oxidative stress and inflammation to improve wound healing in diabetic rats. Naunyn Schmiedebergs Arch Pharmacol 392: 1435-1445, 2019.

30. Kankam HKN, Mehta S and Jain A: Thermal preconditioning for surgery: A systematic review. J Plast Reconstr Aesthet Surg 73 1645-1664, 2020.

31. Park C, Lee H, Noh JS, Jin CY, Kim GY, Hyun JW, Leem SH and Choi YH: Hemistepsin A protects human keratinocytes against hydrogen peroxide-induced oxidative stress through activation of the Nrf2/HO-1 signaling pathway. Arch Biochem Biophys 691: 108512,2020

32. Jackson JW, Rivera-Marquez GM, Beebe K, Tran AD, Trepel JB, Gestwicki JE, Blagg BSJ, Ohkubo $\mathrm{S}$ and Neckers LM: Pharmacologic dissection of the overlapping impact of heat shock protein family members on platelet function. J Thromb Haemost 18: 1197-1209, 2020
33. Matsunobu T, Satoh Y, Ogawa K and Shiotani A: Heme oxygenase-1 expression in the guinea pig cochlea induced by intense noise stimulation. Acta Otolaryngol Suppl: 18-23, 2009.

34. Harder Y, Amon M, Schramm R, Georgi M, Banic A, Erni D and Menger MD: Heat shock preconditioning reduces ischemic tissue necrosis by heat shock protein (HSP)-32-mediated improvement of the microcirculation rather than induction of ischemic tolerance. Ann Surg 242: 869-878, discussion 878-869, 2005.

35. Tian W, Bonkovsky HL, Shibahara S and Cohen DM: Urea and hypertonicity increase expression of heme oxygenase- 1 in murine renal medullary cells. Am J Physiol Renal Physiol 281: F983-F991, 2001.

36. Rücker M, Schäfer T, Roesken F, Spitzer WJ, Bauer M and Menger MD: Local heat-shock priming-induced improvement in microvascular perfusion in osteomyocutaneous flaps is mediated by heat-shock protein 32. Br J Surg 88: 450-457, 2001.

37. Chang YC,Lai CC, Lin LF, Ni WF and Tsai CH: The up-regulation of heme oxygenase-1 expression in human gingival fibroblasts stimulated with nicotine. J Periodontal Res 40: 252-257, 2005.

38. Contaldo C, Harder Y, Plock J, Banic A, Jakob SM and Erni D: The influence of local and systemic preconditioning on oxygenation, metabolism and survival in critically ischaemic skin flaps in pigs. J Plast Reconstr Aesthet Surg 60: 1182-1192, 2007.

39. Schürmann C, Seitz O, Klein C, Sader R, Pfeilschifter J, Mühl H, Goren I and Frank S: Tight spatial and temporal control in dynamic basal to distal migration of epithelial inflammatory responses and infiltration of cytoprotective macrophages determine healing skin flap transplants in mice. Ann Surg 249: 519-534, 2009.

40. Chen YH, Lin SJ, Lin MW, Tsai HL, Kuo SS, Chen JW, Charng MJ, Wu TC, Chen LC, Ding YA, et al: Microsatellite polymorphism in promoter of heme oxygenase-1 gene is associated with susceptibility to coronary artery disease in type 2 diabetic patients. Hum Genet 111: 1-8, 2002.

41. Schillinger M, Exner M, Mlekusch W, Ahmadi R, Rumpold H, Mannhalter C, Wagner O and Minar E: Heme oxygenase-1 genotype is a vascular anti-inflammatory factor following balloon angioplasty. J Endovasc Ther 9: 385-394, 2002.

42. Whitington PF, Moscioni AD and Gartner LM: The effect of tin (IV)-protoporphyrin-IX on bilirubin production and excretion in the rat. Pediatr Res 21: 487-491, 1987.

43. Vreman HJ, Ekstrand BC and Stevenson DK: Selection of metalloporphyrin heme oxygenase inhibitors based on potency and photoreactivity. Pediatr Res 33: 195-200, 1993.

44. Elbirt KK and Bonkovsky HL: Heme oxygenase: Recent advances in understanding its regulation and role. Proc Assoc Am Physicians 111: 438-447, 1999.

45. Adach W, Błaszczyk M and Olas B: Carbon monoxide and its donors-chemical and biological properties. Chem Biol Interact 318: 108973, 2020.

46. Sorrenti V: Editorial of special issue 'protective and detrimental role of heme oxygenase-1'. Int J Mol Sci 20: 4744, 2019.

47. Sha JY, Zhou YD, Yang JY, Leng J, Li JH, Hu JN, Liu W, Jiang S, Wang Y P, Chen C and Li W: Maltol (3-Hydroxy-2-methyl-4-pyrone) slows d-galactose-induced brain aging process by damping the Nrf2/HO-1-mediated oxidative stress in mice. J Agric Food Chem 67: 10342-10351, 2019.

48. Schallner N, Romão CC, Biermann J, Lagrèze WA, Otterbein LE, Buerkle H, Loop T and Goebel U: Carbon monoxide abrogates ischemic insult to neuronal cells via the soluble guanylate cyclase-cGMP pathway. PLoS One 8: e60672, 2013.

49. Ndisang JF, Wu L, Zhao W and Wang R: Induction of heme oxygenase- 1 and stimulation of cGMP production by hemin in aortic tissues from hypertensive rats. Blood 101: 3893-3900, 2003.

50. Motterlini R and Otterbein LE: The therapeutic potential of carbon monoxide. Nat Rev Drug Discov 9: 728-743, 2010.

51. Balla G, Jacob HS, Balla J, Rosenberg M, Nath K, Apple F, Eaton JW and Vercellotti GM: Ferritin: A cytoprotective antioxidant strategem of endothelium. J Biol Chem 267: 18148-18153, 1992.

52. Vinchi F, De Franceschi L, Ghigo A, Townes T, Cimino J, Silengo L, Hirsch E, Altruda F and Tolosano E: Hemopexin therapy improves cardiovascular function by preventing heme-induced endothelial toxicity in mouse models of hemolytic diseases. Circulation 127: 1317-1329, 2013.

53. Fang R and Aust AE: Induction of ferritin synthesis in human lung epithelial cells treated with crocidolite asbestos. Arch Biochem Biophys 340: 369-375, 1997. 
54. Pamplona A, Ferreira A, Balla J, Jeney V, Balla G, Epiphanio S Chora A, Rodrigues CD, Gregoire IP, Cunha-Rodrigues M, et al: Heme oxygenase-1 and carbon monoxide suppress the pathogenesis of experimental cerebral malaria. Nat Med 13: 703-710, 2007.

55. Freitas A, Alves-Filho JC, Secco DD, Neto AF, Ferreira SH, Barja-Fidalgo $\mathrm{C}$ and Cunha FQ: Heme oxygenase/carbon monoxide-biliverdin pathway down regulates neutrophil rolling, adhesion and migration in acute inflammation. BrJ Pharmacol 149: 345-354, 2006

56. Cepinskas G, Katada K, Bihari A and Potter RF: Carbon monoxide liberated from carbon monoxide-releasing molecule CORM-2 attenuates inflammation in the liver of septic mice. Am J Physiol Gastrointest Liver Physiol 294: G184-G191, 2008.

57. Mizuguchi S, Stephen J, Bihari R, Markovic N, Suehiro S, Capretta A, Potter RF and Cepinskas G: CORM-3-derived CO modulates polymorphonuclear leukocyte migration across the vascular endothelium by reducing levels of cell surface-bound elastase. Am J Physiol Heart Circ Physiol 297: H920-H929, 2009.

58. Tsoyi K, Lee TY,Lee YS, Kim HJ, Seo HG, Lee JH and Chang KC: Heme-oxygenase-1 induction and carbon monoxide-releasing molecule inhibit lipopolysaccharide (LPS)-induced high-mobility group box 1 release in vitro and improve survival of mice in LPSand cecal ligation and puncture-induced sepsis model in vivo. Mol Pharmacol 76: 173-182, 2009.

59. Lancel S, Hassoun SM, Favory R, Decoster B, Motterlini R and Neviere R: Carbon monoxide rescues mice from lethal sepsis by supporting mitochondrial energetic metabolism and activating mitochondrial biogenesis. J Pharmacol Exp Ther 329: 641-648, 2009.

60. Chung SW, Liu X, Macias AA, Baron RM and Perrella MA Heme oxygenase-1-derived carbon monoxide enhances the host defense response to microbial sepsis in mice. J Clin Invest 118 : 239-247, 2008

61. Desmard M, Davidge KS, Bouvet O, Morin D, Roux D, Foresti R, Ricard JD, Denamur E, Poole RK, Montravers P, et al: A carbon monoxide-releasing molecule (CORM-3) exerts bactericidal activity against pseudomonas aeruginosa and improves survival in an animal model of bacteraemia. FASEB J 23: 1023-1031, 2009.

62. Morse D, Pischke SE, Zhou Z, Davis RJ, Flavell RA, Loop T, Otterbein SL, Otterbein LE and Choi AM: Suppression of inflammatory cytokine production by carbon monoxide involves the JNK pathway and AP-1. J Biol Chem 278: 36993-36998, 2003.

63. Otterbein LE, Bach FH, Alam J, Soares M, Tao Lu H, Wysk M, Davis RJ, Flavell RA and Choi AM: Carbon monoxide has anti-inflammatory effects involving the mitogen-activated protein kinase pathway. Nat Med 6: 422-428, 2000.

64. Chen B, Guo L, Fan C, Bolisetty S, Joseph R, Wright MM, Agarwal A and George JF: Carbon monoxide rescues heme oxygenase-1-deficient mice from arterial thrombosis in allogeneic aortic transplantation. Am J Pathol 175: 422-429, 2009.

65. Brüne B and Ullrich V: Inhibition of platelet aggregation by carbon monoxide is mediated by activation of guanylate cyclase. Mol Pharmacol 32: 497-504, 1987.

66. Wang R: Resurgence of carbon monoxide: An endogenous gaseous vasorelaxing factor. Can J Physiol Pharmacol 76: 1-15, 1998

67. Varadi J, Lekli I, Juhasz B, Bacskay I, Szabo G, Gesztelyi R, Szendrei L, Varga E, Bak I, Foresti R, et al: Beneficial effects of carbon monoxide-releasing molecules on post-ischemic myocardial recovery. Life Sci 80: 1619-1626, 2007.

68. Guo Y, Stein AB, Wu WJ, Tan W, Zhu X, Li QH, Dawn B, Motterlini R and Bolli R: Administration of a CO-releasing molecule at the time of reperfusion reduces infarct size in vivo. Am J Physiol Heart Circ Physiol 286: H1649-H1653, 2004.

69. Józkowicz A, Huk I, Nigisch A, Weigel G, Dietrich W, Motterlini R and Dulak J: Heme oxygenase and angiogenic activity of endothelial cells: Stimulation by carbon monoxide and inhibition by tin protoporphyrin-IX. Antioxid Redox Signal 5: $155-162,2003$

70. Soares MP, Usheva A, Brouard S, Berberat PO, Gunther L, Tobiasch E and Bach FH: Modulation of endothelial cell apoptosis by heme oxygenase-1-derived carbon monoxide. Antioxid Redox Signal 4: 321-329, 2002.

71. Clark JE, Naughton P, Shurey S, Green CJ, Johnson TR, Mann BE, Foresti R and Motterlini R: Cardioprotective actions by a water-soluble carbon monoxide-releasing molecule. Circ Res 93: e2-e8, 2003.
72. Sato K, Balla J, Otterbein L, Smith RN, Brouard S, Lin Y, Csizmadia E, Sevigny J, Robson SC, Vercellotti G, et al: Carbon monoxide generated by heme oxygenase-1 suppresses the rejection of mouse-to-rat cardiac transplants. J Immunol 166: 4185-4194, 2001.

73. Sandouka A, Fuller BJ, Mann BE, Green CJ, Foresti R and Motterlini R: Treatment with CO-RMs during cold storage improves renal function at reperfusion. Kidney Int 69: 239-247, 2006.

74. Jansen T and Daiber A: Direct antioxidant properties of bilirubin and biliverdin. Is there a role for biliverdin reductase? Front Pharmacol 3: 30, 2012.

75. Maines MD, Miralem T, Lerner-Marmarosh N, Shen J and Gibbs PE: Human biliverdin reductase, a previously unknown activator of protein kinase C betaII. J Biol Chem 282: 8110-8122, 2007.

76. Gibbs PE, Tudor C and Maines MD: Biliverdin reductase: More than a namesake-the reductase, its peptide fragments, and biliverdin regulate activity of the three classes of protein kinase $\mathrm{C}$. Front Pharmacol 3: 31, 2012.

77. Lerner-Marmarosh N, Shen J, Torno MD, Kravets A, Hu Z and Maines MD: Human biliverdin reductase: A member of the insulin receptor substrate family with serine/threonine/tyrosine kinase activity. Proc Natl Acad Sci USA 102: 7109-7114, 2005.

78. Jansen T, Hortmann M, Oelze M, Opitz B, Steven S, Schell R, Knorr M, Karbach S, Schuhmacher S, Wenzel P, et al: Conversion of biliverdin to bilirubin by biliverdin reductase contributes to endothelial cell protection by heme oxygenase-1-evidence for direct and indirect antioxidant actions of bilirubin. J Mol Cell Cardiol 49: 186-195, 2010.

79. Pae HO, Son Y, Kim NH, Jeong HJ, Chang KC and Chung HT: Role of heme oxygenase in preserving vascular bioactive NO. Nitric Oxide 23: 251-257, 2010

80. Eppihimer MJ and Granger DN: Ischemia/reperfusion-induced leukocyte-endothelial interactions in postcapillary venules. Shock 8: 16-25, 1997.

81. Kunkel EJ, Jung U, Bullard DC, Norman KE, Wolitzky BA, Vestweber D, Beaudet AL and Ley K: Absence of trauma-induced leukocyte rolling in mice deficient in both $\mathrm{P}$-selectin and intercellular adhesion molecule 1. J Exp Med 183: 57-65, 1996.

82. Menger MD and Vollmar B: Adhesion molecules as determinants of disease: From molecular biology to surgical research. Br J Surg 83: 588-601, 1996.

83. Menger MD, Pelikan S, Steiner D and Messmer K: Microvascular ischemia-reperfusion injury in striated muscle: Significance of 'reflow paradox'. Am J Physiol 263: H1901-H1906, 1992.

84. Rücker M, Schäfer T, Roesken F, Spitzer WJ, Bauer M and Menger MD: Reduction of inflammatory response in composite flap transfer by local stress conditioning-induced heat-shock protein 32. Surgery 129: 292-301, 2001.

85. Taleb S, Moghaddas P, Rahimi Balaei M, Taleb S, Rahimpour S, Abbasi A, Ejtemaei-Mehr S and Dehpour AR: Metformin improves skin flap survival through nitric oxide system. J Surg Res 192: 686-691, 2014

86. Han HH, Lim YM, Park SW, Lee SJ, Rhie JW and Lee JH: Improved skin flap survival in venous ischemia-reperfusion injury with the use of adipose-derived stem cells. Microsurgery 35: 645-652, 2015

87. Forrester SJ, Kikuchi DS, Hernandes MS, Xu Q and Griendling KK: Reactive oxygen species in metabolic and inflammatory signaling. Circ Res 122: 877-902, 2018.

88. Lin CC, Hsiao LD, Cho RL and Yang CM: Carbon monoxide releasing molecule-2-upregulated ROS-dependent heme oxygenase-1 axis suppresses lipopolysaccharide-induced airway inflammation. Int J Mol Sci 20: 3157, 2019.

89. Shi Y, Liang XC, Zhang H, Sun Q, Wu QL and Qu L: Combination of quercetin, cinnamaldehyde and hirudin protects rat dorsal root ganglion neurons against high glucose-induced injury through Nrf-2/HO-1 activation and NF- $\kappa \mathrm{B}$ inhibition. Chin J Integr Med 23: 663-671, 2017.

90. Brouard S, Otterbein LE, Anrather J, Tobiasch E, Bach FH, Choi AM and Soares MP: Carbon monoxide generated by heme oxygenase 1 suppresses endothelial cell apoptosis. J Exp Med 192: 1015-1026, 2000.

91. Edmunds MC, Czopek A, Wigmore SJ and Kluth DC: Paradoxical effects of heme arginate on survival of myocutaneous flaps. Am J Physiol Regul Integr Comp Physiol 306: R10-R22, 2014. 
92. Harder Y, Amon M, Schramm R, Rücker M, Scheuer C, Pittet B, Erni D and Menger MD: Ischemia-induced up-regulation of heme oxygenase-1 protects from apoptotic cell death and tissue necrosis. J Surg Res 150: 293-303, 2008.

93. Harder Y, Contaldo C, Klenk J, Banic A, Jakob SM and Erni D: Improved skin flap survival after local heat preconditioning in pigs. J Surg Res 119: 100-105, 2004.

94. Harder Y, Amon M, Georgi M, Scheuer C, Schramm R, Rücker M, Pittet B, Erni D and Menger MD: Aging is associated with an increased susceptibility to ischaemic necrosis due to microvascular perfusion failure but not a reduction in ischaemic tolerance. Clin Sci (Lond) 112: 429-440, 2007.

95. Kubulus D, Roesken F, Amon M, Rücker M, Bauer M, Bauer I and Menger MD: Mechanism of the delay phenomenon: Tissue protection is mediated by heme oxygenase-1. Am J Physiol Heart Circ Physiol 287: H2332-H2340, 2004.

96. Sun Y, Li QF, Zhang Y, Hu R and Jiang H: Isoflurane preconditioning increases survival of rat skin random-pattern flaps by induction of HIF-1 $\alpha$ expression. Cell Physiol Biochem 31: 579-591, 2013.

97. Chiang SK, Chen SE and Chang LC: A dual role of heme oxygenase-1 in cancer cells. Int J Mol Sci 20: 39, 2018.
98. Nitti M, Piras S, Brondolo L, Marinari UM, Pronzato MA and Furfaro AL: Heme oxygenase 1 in the nervous system: Does it favor neuronal cell survival or induce neurodegeneration? Int J Mol Sci 19: 2260, 2018.

99. Hopper CP, Meinel L, Steiger C and Otterbein LE: Where is the clinical breakthrough of heme oxygenase-1/carbon monoxide therapeutics? Curr Pharm Des 24: 2264-2282, 2018.

100. Steiger C, Hermann C and Meinel L: Localized delivery of carbon monoxide. Eur J Pharm Biopharm 118: 3-12, 2017.

101. Bereczki D Jr, Balla J and Bereczki D: Heme oxygenase-1: Clinical relevance in ischemic stroke. Curr Pharm Des 24: 2229-2235, 2018.

102. Szabo IL, Kenyeres A, Szegedi A and Szollosi AG: Heme oxygenase and the skin in health and disease. Curr Pharm Des 24: 2303-2310, 2018.

103. Haines DD and Tosaki A: Role of heme oxygenases in cardiovascular syndromes and co-morbidities. Curr Pharm Des 24: 2322-2325, 2018.

This work is licensed under a Creative Commons Attribution-NonCommercial-NoDerivatives 4.0 International (CC BY-NC-ND 4.0) License. 